\title{
Bowling Modification to Increase the Basic Movement of Throwing in the Learning of Physical Education
}

\author{
Kartini \\ Master Program in Sports Science \\ Universitas Negeri Yogyakarta \\ Yogyakarta, Indonesia \\ kartini.pjkr@gmail.com
}

\author{
Eddy Purnomo \\ Faculty of Sport Science \\ Universitas Negeri Yogyakarta \\ Yogyakarta, Indonesia \\ eddy_purnomo@uny.ac.id
}

\begin{abstract}
- inonnative learning is one of the numerous ways that can be used in increasing students' interest and enthusiasm to participate in teaching and learning activities. The use of different methods, models, approaches or special modifications according to the needs of learners can serve as a means of helping or reducing obstacles that occur in the process of learning. The purpose of this preliminary study was to analyze in accordance with related research the need for modification in bowling game in the learning of physical education. The method used in this study was survey. The subject of this research included three teachers of physical education, sport and health in primary schools of Yogyakarta, Indonesia. The instrument used in the collection of data was closed questionnaire. The data was analyzed using qualitative descriptive statistics. The results of the analysis showed that there were problems relating to physical education learning as a result of lack of teaching material for basic throwing motion skill. Based on the analysis of the problem, the authors want tried to modify the bowling game in the learning of physical education for improvement of basic throwing motion intended for elementary school students.
\end{abstract}

Keywords - bowling, learning, basic motion throwing

\section{INTRODUCTION}

Lesson plans are one of the key factors in the education process. Several methods of learning such as holding special workshops can provide information on how to develop better learning plans [1]. The ability to develop teaching materials should be something that must be continuously improved by every teacher, including physical education teachers. Physical education teachers should have the ability of attracting students' attention in accordance with learning goals and needs despite the lack of sports equipment. Physical education teachers must be creative and be able to provide a positive environment in alleviating and overcoming obstacles related to existing facilities and infrastructure in schools [2]. Each teaching plan is also based on a maximum design, therefore in teaching, it is best to use an appropriate theory or model according to the initial plan [3].

Active learning occurs when the teacher connects material that is relevant to students' lives. The best teacher gives high expectations, challenges students outside their comfort zone, makes collaborative and interactive learning, and displays attention and concern for the learning and growth of the students [4]. Students feel active when they directly participate in the learning process. They have preference for active learning that implicitly recognizes their behavioral, cognitive and social dimensions without the need to explore their own attitudes and value [5]. Measured and systematic physical activity in the learning process can be an avenue for students to be active in the development of movement skills and other physical skills. Physical activity with various sports education models can encourage and motivate students to be directly involved in acquiring experiences that are sports-based [6].

A varied learning process can certainly have positive impact on learning success. Modification of games or sports can be one of the was to develop the required teaching materials. Modification of bowling in the learning of physical education is a step that can be explored in support of learning process especially for the purpose of increasing the basic motion of throwing in big ball games.

\section{METHODS}

This study made use of survey method to carry out the research. The subject of this research included three physical education, sports and health teachers of primary school in Yogyakarta, Indonesia. The instrument used in data collection was a closed questionnaire. Data analysis techniques used was qualitative descriptive statistics.

\section{RESULT}

Based on the survey conducted on preliminary studies on physical education learning about basic throwing motion material, several problems were discovered and they include: 1) Not all basic throwing motion skills are taught in learning, 2) Lack of application and development of basic throwing motion materials reduce learning, 3) Lack of introduction of a game or sport that is rarely known such as bowling game, 4) Lack of learning process that varies and combines the basic throwing down motion which makes it impossible to measure the skills possessed by the students, 5) Absence of innovative learning with respect to basic throwing motion material especially for the bottom throw.

\section{DISCUSSION}

The determination of design and learning plans in the established curriculum must also have its own functions and 
objectives. In the same vein, physical education learning must always make physical activity a distinctive feature in the application of teaching and learning activities in schools. Systematic and measurable physical activity can be used in achieving some important aspects of educational goals that include cognitive, affective and psychomotor aspects. Teachers as teaching staff or educators in schools are required to have creative and innovative abilities. One of abilities is to create a new innovation in learning material that is interesting and fun in order to motivate and facilitate students in participating in teaching and learning activities carried out so as to achieve the educational goals of the learning. In the curriculum set by the Indonesian government regarding physical, sports and health education curricula, especially for grade 5, there are basic competencies that must be applied, one of which is the basic throwing motion. The basic throwing or simply 'throwing' is included as a manipulative motion. Throwing is a complex manipulative skill where one or two hands are used to throw an object away from the body. Throwing can be done by throwing down, throwing the head, throwing the arm or throwing the side of the arm [7].

Based on observations that have been made in several elementary schools in Yogyakarta, Indonesia, there are several problems concerning basic throwing motion materials. Not all basic throwing movements are taught in physical education learning, especially the lower throws. Lack of teaching materials for basic throwing down material is one of the challenges that must be resolved. Bowling game modification can be one of the new learning materials that can be used in big ball game in addition to the basic throwing motion materials especially for the bottom throw. The ball rolling technique which has been identified as the basic throwing can be developed and taught through physical activity. Therefore, the game of bowling can be an attractive teaching material in the big ball game for physical education learning. The resulting game is designed to include playing, simple rules, and supporting infrastructure that can also be found in the conventional bowling game.

Besides being able to provide new space in physical activity, modification of the bowling game combines aspects expected in the goal of physical education including affective, cognitive and psychomotor. It is important to point out that affective aspects include collaboration or teamwork, discipline in playing games, individual and team trust, and sportsmanship in the game. Cognitive aspects include mastering the game, tactics when throwing balls, and strategies in team play. Psychomotor aspects include footwork when starting, arm swing when rolling the ball and end attitude after the game. The basic throwing motion in the game can be used in meeting the needs of students to increas their basic motion of throw.

\section{CONCLUSION}

Based on the results of this preliminary study, it can be concluded that the need for the development of bowling games as a means of adding teaching materials to the basic throwing down skills in physical education learning is essential.

\section{ACKNOWLEDGMENT}

The author thanks all elementary school students involved as well as all physical, sports and health education teachers who contributed to this preliminary study. The author also thanked the lecturers and friends of students of the sports science study program at the Postgraduate Program of Yogyakarta State University, Yogyakarta.

\section{REFERENCES}

[1] J. Nesari and M. Heidari, "The important role of lesson plan on educational achievement of iranian efl teachers' attitudes," International Journal of Foreign Language Teaching \& Research, vol. 3, no. 5, 2014.

[2] K. D. Brubaker, The Importance Of Physical Education In Today's Schools, Ashland: Ashland University, 2011.

[3] D. Rosdiani, Perencanaan Pembelajaran Dalam Pendidikan Jasmani dan Kesehatan, Bandung: Alfabeta, 2013

[4] A. Paolini, "Enhancing teaching effectiveness and student learning outcomes," The Journal of Effective Teaching, vol. 15, no. 1, pp. 20-33, 2015.

[5] F. Aksit, H. Niemi and A. Nevgi, "Why is active learning so difficult to implement: the turkish case," Australian Journal of Teacher Education, vol. 41 , no. $4,2016$.

[6] D. Perlman, "The influence of the sport education model on amotivated students' in-class physical activity," European Physical Education Review, vol. 18, no. 3, pp. 335-345, 2012.

[7] Sudarsini, Gerak Dasar dan Gerak Irama, Malang: Gunung samudera, 2016. 